\title{
Editorial
}

\section{Between Frankfurt and Karlsruhe: The Move, the Law and the INSTITUTIONS}

On 26 July 2012 European Central Bank president Mario Draghi announced in a speech that he was seeking to stop speculation against the euro. 'Within our mandate, the ECB is ready to do whatever it takes to preserve the euro. And believe me, it will be enough. ${ }^{1}$ This was taken as an announcement that the Bank would buy government bonds in the secondary markets; and indeed, hardly two weeks later it released a press statement setting out the intended programme of 'Outright Monetary Transactions' (OMT). ${ }^{2}$

A good year later, two facts stand out: Draghi's bold declaration of intent has not been followed by any actual purchases, yet the move was successful in stemming the speculative attack on the euro, for the time being. The announcement is now generally ranked among the several key moves made by the Union in its confrontation with the financial markets, also known as the Eurozone crisis. Once this confrontation is past and the euro is still standing, the Union's authority will have been enhanced and its institutional structure overhauled. Not, of course, through Draghi's gambit alone. But the announcement will also have to be read into the Union's new authority and into its institutional evolution. How can its contribution to that evolution be understood from the perspective of legal scholarship? We would like to offer some thoughts triggered by this question.

The natural starting point for a legal analysis of the development is the question of legal competence. Does actual intervention on the secondary markets fall within the Bank's mandate? Is the announcement to intervene covered? In full accordance with well-established tradition, these questions have been put to the Bundesverfassungsgericht. Even if its judgment is sure to condone Draghi's move, it will be another fine piece of case-law, focussed on sharply discernable points of

\footnotetext{
${ }^{1}$ Transscript on <www.ecb.europa.eu/press/key/date/2012/html/sp120726.en.html>; video on $<$ www.youtube.com/watch?v=Pq1V0aPEO3c $>$, both visited 4 Oct. 2013).

${ }^{2}$ Press release of 6 Sept. 2012, www.ecb.europa.eu/press/pr/date/2012/html/pr120906_1. en.html, visited 4 Oct. 2013.
} 
law and significant in other ways. ${ }^{3}$ In the hearing on 11 June 2013, court president Voßkuhle stressed that he was not interested in whether the action was successful but whether it was legal. 'Otherwise the end alone would justify the means', he is reported to have said (EUobserver, 12 June 2013). From this sharp focus on the legality, we will be able to follow several doctrinal lines leading us to much broader questions. The conflict raised before the German court is one about the division of competences between the Union and member states and the broader struggle over more or less European integration. One could also look at the limits on the German parliament's legislative power and at the question of who, within Germany, ultimately controls European integration, the political elites or the people. It is hard to imagine more wide-ranging constitutional problems condensed into a legal contention.

For us, lawyers, this wider significance is part of the thrill. The importance of case law flows from the fact that the resolutions of legal disputes, apart from settling conflict, are engaging and help our understanding. We lawyers trust court cases to frame contentious large-scale situations into focussed disputes. This method works because concrete cases in some sense provide a meaningful representation of the underlying conflicts.

But there are limits to this representativeness. It is clear that in the case before the Bundesverfassungsgericht, the Eurozone crisis as such can hardly feature. It merely plays the role of some outside challenge to our current political system, as if it were any other natural disaster. The case before the German court does not represent the concrete standoff between the markets and the public authority with regard to financial assets, regulative measures, rhetorical persuasion - that are engaged in defence of the euro. But it is in this standoff that one will find the gains and the changes from President Draghi's announcement. In terms of institutional evolution, the remarkable thing about Draghi's move is simply not a question of legality or competence.

Does that mean that a fuller institutional reflection on the episode and on the new situation is beyond the ken of legal scholarship? We would hope it is not. If, in the institutional perspective, the move's significance does not lie in the question of legality, we have to see how to widen the perspective. The following points suggest themselves, amongst others.

The first concerns sources of our understanding. Draghi's announcement was not a legal act but it was authoritative. We need to include legally non-binding acts and other forms of authority, next to the binding ones, in our understanding of the situation and its evolution.

The second concerns the terms of our understanding. We need to use a widerthan-legal vocabulary to read the events and developments. Draghi took responsi-

${ }^{3}$ BVerfG, pending cases 2 BvR 1390/12 etc. 
bility for the survival of the euro and claimed fresh authority for his Bank through this action. The law is part of this, of course: the legal claim that he acted within his mandate was a part of his taking responsibility.

The third point concerns our understanding of court judgments. Apart from looking at their core of settling a dispute, and at the new criteria they put forward, and other elements of their applicability, we should read these rulings themselves also as acts of wider authority and responsibility, and other qualities not strictly legal yet significant. The Bundesverfassungsgericht, even if strictly not concerned with the success of the Bank's move, will surely add legitimacy and authority to it.

The fourth point is about how to comment on this. From such wider perspectives as above, court rulings are often not conclusive but, instead, they are a move in a larger institutional game. They need to be read as part of an interaction. Courts are not only arbiters but are also participants. For legal scholarship, it is natural to hike onto the ruling's normative drive and carry this on into further criticism or approval. However, when we see courts as participants or actors, in an institutional reading, we need to hold our judgment and try to read the play and the situation. What new relationship, not with other courts but with an EU institution, is the Bundesverfassungsgericht drawn into in this case?

Fifth of all, this allows a longer time frame than the one prompted by action, judgment and comment. Institutional relationships do not develop straight from acts or from judgments, nor are they intelligible as such. Draghi's announcement and the Bundesverfassungsgericht's ruling are sure to count as key developments. But it may take quite a while, and a wide angle, to know their consequence.

These ways of widening the perspective are certainly not new. But we believe they deserve some encouragement. The constant feeding of our debates by fresh judgments from constitutional courts, in Germany and elsewhere, is most welcome. Those judgments help us to ask - and partly to answer - great questions of law. But they tend to divert our attention from other developments of no lesser significance. Even if broad institutional questions cannot easily be decided by law, it is still worth asking them.

WTE/BM 